ACTA VET. BRNO 2001, 70: 381-385

\title{
CONCENTRATION OF PHYTIC ACID IN FAECES OF CALVES FED STARTER DIETS
}

\author{
D. DUŠKOVÁ ${ }^{1}$, R. DVOŘÁK ${ }^{2}$, V. RADA ${ }^{3}$, J. DOUBEK $^{2}$, M. MAROUNEK $^{1}$ \\ ${ }^{1}$ Institute of Animal Physiology and Genetics, Czech Academy of Sciences, Prague, Czech Republic \\ ${ }^{2}$ Faculty of Veterinary Medicine, University of Veterinary and Pharmaceutical Sciences, Brno, Czech Republic \\ ${ }^{3}$ Faculty of Agronomy, Czech University of Agriculture Prague, Prague, Czech Republic \\ Received May 22, 2001 \\ Accepted October 31, 2001 \\ Abstract \\ Dušková D., R. Dvořák, V. Rada, J. Doubek, M. Marounek: Concentration of Phytic \\ Acid in Faeces of Calves Fed Starter Diets. Acta Vet. Brno 2001, 70: 381-385. \\ Ruminants utilize phytic acid well. The digestive system of young calves, however, is less \\ developed than that of adult animals. The aim of our study was to decide whether phytic acid \\ hydrolysis in the digestive tract of calves is complete or not. Thus, rectal samples of faeces were \\ collected from 16 crossbred calves fed starter diets. Faeces of calves were sampled at the age \\ of 1, 6 and 13 weeks. In starter concentrates and faeces the phytic acid content was determined \\ by capillary isotachophoresis. Two commercial starters containing 9.17 and $12.80 \mathrm{~g}$ of phytic \\ acid per kg of dry matter ( 37.6 and $50.1 \%$ of the total $\mathrm{P}$ ) were offered ad libitum from the $4^{\text {th }}$ \\ day of life. Calves were weaned from milk at the age of 6 weeks. Phytic acid was determined \\ in 30 out of 37 faecal samples. Its concentration varied widely from $1 \mathrm{mg}$ to $2.34 \mathrm{~g}$ per $\mathrm{kg}$ of \\ dry matter. In some samples, the quantity of phytic acid was insufficient for a precise \\ determination. Phytic acid phosphorus represented 0 to $8.9 \%$ of the total $\mathrm{P}$ in faeces. The \\ highest phytic acid concentrations were found in faeces of calves at the age of 6 weeks, just \\ after weaning. On average, faeces of 1,6 and 13 weeks old calves contained $8 \pm 4,477 \pm 265$ \\ and $275 \pm 211 \mathrm{mg}$ phytic acid per $\mathrm{kg}$ DM, respectively (means \pm SEM). It can be concluded that \\ a part of ingested phytic acid apparently escapes the hydrolysis in the digestive tract of calves \\ fed commercial starters.
}

Nutrition, concentrated feed, phosphorus

Concentrated feeds for cattle contain components rich in phytic acid: cereal grains, grain by-products and oilseed meals. Contrary to monogastric animals, ruminants utilize phytic acid (myo-inositolhexaphosphoric acid) very well. In an early study, Reid et al. (1947) reported that phytic acid phosphorus was liberated in the rumen of sheep, and later Raun et al. (1956) found that calcium phytate was as available to rumen microorganisms as inorganic phosphate when tested by an artificial rumen technique. Several authors concluded that phytic acid was hydrolyzed to inositol and inorganic phosphate in high producing dairy cows consuming large quantities of concentrates (Clark et al. 1986; Morse et al. 1992; Marounek et al. 2000a). Study of Yanke et al. (1998) demonstrated the presence of phytase activity in five species of rumen bacteria, in particular Selenomonas ruminantium. The hydrolysis of phytic acid in the digestive tract of calves has received less attention. Nels on et al. (1976) using a ferric chloride precipitation method analysed the feed and faeces of weaned calves, 9 weeks of age, fed a concentrate composed primarily of ground maize, oats and soybean meal. The authors concluded that less than $1 \%$ of the ingested phytic acid was recovered from the faeces.

The objective of this study was to reexamine the phytic acid presence in faeces of calves using a more advanced analytical technique. Phytic acid concentration was measured in feeds and faeces of calves fed starter concentrates before and after weaning by means of the capillary isotachophoresis.

Address for correspondence:

Prof. ing. M. Marounek, DrSc.

Institute of Animal Physiology and Genetics

Czech Academy of Sciences
Přatelství 560, CZ - 10400 Prague 10-Uhříněves, Czech Republic

Phone: +420 2/6771 1730

Fax: +420 2/67710803

E-mail: marounek@iapg.cas.cz 
Calves

\section{Materials and Methods}

Rectal samples of faeces were obtained from 16 crossbred calves (Red Holstein $\times$ Czech spotted Ayrshire) of both sexes, housed in individual straw-bedded hutches till weaning, and later in pens. After birth, calves were fed colostrum for the first 5 days of life, then milk till weaning at 6 weeks of age. Starter concentrates were offered $a d$ libitum from the $4^{\text {th }}$ day of life. Two starter concentrates were compared: a starter Standard and a starter Telstar (ZEA Sedmihorky, Czech Republic). The former starter contained: extracted soybean meal (28.5\%), ground maize $(20 \%)$, rolled oats $(17 \%)$, rolled barley $(12 \%)$, wheat bran $(7.8 \%)$, linseed $(6 \%)$, whey $(4 \%)$, malt $(1.5 \%)$, mineral mix $(2.7 \%)$, vitamin mix $(0.5 \%)$. The latter starter contained $50 \%$ of whole maize grains and a granulated concentrate. The concentrate consisted of products and by-products prepared from grain, oil-seeds and nuts, products and by-products of the sugar industry, mineral mix, copper sulphate pentahydrate, sweetener, vitamins A, $\mathrm{D}, \mathrm{E}$ and antioxidants. No other details on composition of this starter were available. The concentration of nutrients in both starters is shown in Table 1 . From the $11^{\text {th }}$ week of age, all calves had access to good quality meadow hay. Table 2 presents average daily consumption of feeds. Rectal samples were collected at $11.00 \mathrm{~h}$, from 8 calves fed the starter Standard and from 8 calves fed the starter Telstar. Faeces of calves were sampled at the age of 1,6 (just after weaning) and 13 weeks. Faeces were frozen and freeze dried before analysis.

Table 1

Chemical composition of starters

\begin{tabular}{|l|c|c|}
\hline \multirow{2}{*}{ Nutrient $\left(\mathrm{g} / \mathrm{kg} \mathrm{DM}^{\mathrm{a}}\right)$} & \multicolumn{2}{|c|}{ Starter } \\
\cline { 2 - 3 } Crude protein & Standard & Telstar \\
\hline Fibre & 225.60 & 179.50 \\
\hline Fat & 57.20 & 42.80 \\
\hline Ash & 36.20 & 26.20 \\
\hline Ca & 68.80 & 68.50 \\
\hline P & 10.91 & 11.02 \\
\hline Phytic acid & 6.86 & 7.20 \\
\hline
\end{tabular}

a Starters Standard and Telstar contained 88.66 and $87.17 \%$ of dry matter (DM), respectively.

Table 2

Average daily feed intake of calves

\begin{tabular}{|c|c|c|c|c|}
\hline \multirow{2}{*}{ Age (weeks) } & \multirow{2}{*}{ Milk (1) } & \multicolumn{2}{|c|}{ Starter $(\mathrm{kg})$} & \multirow{2}{*}{ Hay $(\mathrm{kg})$} \\
\cline { 2 - 5 } & 4 & 0.35 & Telstar & - \\
\hline $1-6$ & - & 1.88 & 0.48 & - \\
$7-10$ & - & 2.75 & 3.54 & 0.8 \\
\hline
\end{tabular}

\section{Analyses}

Phytic acid in starters and faeces was determined by capillary electrophoresis (Dušková et al. 2001). Briefly, phytic acid was extracted by $0.95 \mathrm{M} \mathrm{HCl}$ and separated from interfering compounds by precipitation with ferric chloride. Ferric phytate was dissolved by $1.5 \mathrm{M} \mathrm{NaOH}$. The ferric hydroxide precipitate was removed by centrifugation and the supernatant neutralized by adding catex Dowex $50 \mathrm{WX} 8$ in $\mathrm{H}^{+}$-cycle. Catex instead of $\mathrm{HCl}$ was used to avoid addition of extra $\mathrm{Cl}^{-}$ions. The solution was analysed employing the column-coupling instrument EA 101 (Villa Labeco, Spišská Nová Ves, Slovakia). The phytic acid zone was identified on the basis of the step height using a standard solution. To verify the presence of phytic acid in faeces of calves, extracts of faeces were precipitated by $\mathrm{FeCl}_{3}$, precipitate dissolved in $\mathrm{NaOH}$, and $\mathrm{Fe}(\mathrm{OH})_{3}$ separated by centrifugation. The supernatant was treated with phytase (Sigma). Controls were prepared using the same procedure but without the phytase addition. Diluted solutions were analysed by isotachophoresis. Determination of phytic acid was made via a regression equation between the concentration of phytic acid in extracts and the zone length in seconds. An external calibration method was used with solutions of the dodecasodium salt of phytic acid (Sigma) as standards.

Protein content of starters was determined using the Kjeltec Auto 1030 Analyser (Tecator AB, Sweden), and fat by means of the Soxtec apparatus from the same company. Calcium and phosphorus were determined by means of 
commercial kits (Lachema Brno, Czech Republic). Other analyses (dry matter, fibre, and ash) were carried out by standard AOAC (1980) procedures.

\section{Results and Discussion}

The zone of phytic acid in extracts of feeds and faeces was well separated from zones of other compounds. In extracts of faeces treated with phytase the zone of phytic acid disappeared and zones of lower inositol phosphates (the phytic acid degradation products) increased (Fig. 1).

Starters Standard and Telstar contained 9.17 and $12.80 \mathrm{~g}$ of phytic acid per $\mathrm{kg} \mathrm{DM}$, respectively (Table 1). Phytic acid thus represented 37.6 and $50.1 \%$ of the total phosphorus in these feeds. As the intake of starters increased with age (Table 2), the daily amount of phytic acid ingested gradually increased from 2.8 and $5.4 \mathrm{~g}$ to 22.4 and $36.8 \mathrm{~g}$ in calves fed Standard and Telstar starter, respectively.

Faeces of nine 1-week-old calves contained 1-47 mg of phytic acid per $1 \mathrm{~kg}$ DM (Fig. 2). In faeces of four calves of this age phytic acid was not detected. In three calves the amount of phytic acid in faeces was too small to carry out the quantitative determination of phytic acid. All analysed samples of faeces of 6-week-old calves except one contained phytic acid. Its amount varied from $7 \mathrm{mg}$ to $2.34 \mathrm{~g}$ per $1 \mathrm{~kg}$ DM. In four 6-week-old calves the amount of phytic acid in faeces sampled, however, was insufficient for a precise determination. In faeces of two 13-week-old calves phytic acid was absent. The quantity of phytic acid in faeces sampled from four calves of this age was not sufficient to determine phytic acid exactly. In faeces of other calves the concentration of phytic acid varied from 79 to $671 \mathrm{mg}$ per $1 \mathrm{~kg}$ DM. On average, faeces of 1,6 and 13 weeks old calves contained $8 \pm 4,477 \pm 265$ and $275 \pm 211 \mathrm{mg}$ of phytic acid per $\mathrm{kg} \mathrm{DM}$, respectively (means $\pm \mathrm{SEM}$ ). The presence of phytic acid in faeces of one-week-old calves was somewhat surprising as no milk replacer containing plant components was fed to calves. Calves at one week of age consumed $20-50 \mathrm{~g}$ of starters daily, i.e. $0.2-0.6 \mathrm{~g}$ of phytic acid per day. Additional source of phytic acid seems to be straw used for bedding. Calves start to consume fibrous materials at this age (Kmet et al. 1990). The content of phytic acid in straw, however, is lower than in grains (Hatzack et al. 2000).

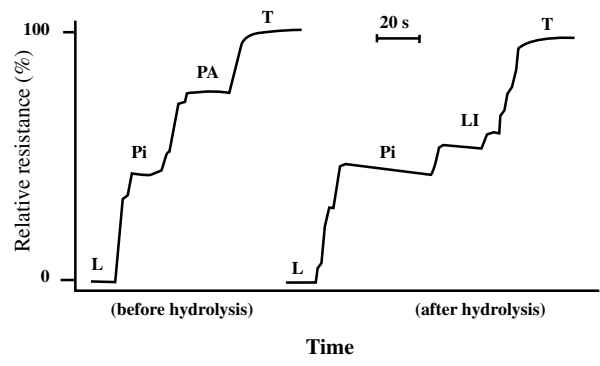

Fig. 1. Isotachopherograms of extracts of faeces of calves before and after hydrolysis of phytic acid by phytase. PA, phytic acid; LI, lower inositol phosphates; Pi, inorganic phosphate; L, leading ion; T, terminating ion.

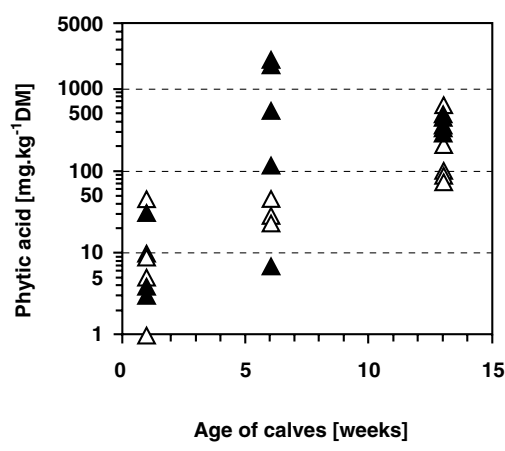

Fig. 2. Concentration of phytic acid in faeces of calves at 1,6 and 13 weeks of age. Open symbols, starter Standard; closed symbols, starter Telstar.

Data on concentration of phytic acid in faeces of young calves are scarce in the available literature. Only Nels on et al. (1976) reported that phytic acid was absent from faeces of 9month-old calves, but traces of phytic acid were recovered from faeces of weaned calves, 9 
weeks old. In our experiment, concentrations of phytic acid much higher than traces were found in faecal samples of several calves. The findings of phytic acid in faeces were highly variable, ranging from those below the limit of detection to $2.34 \mathrm{~g}$ per $\mathrm{kg} \mathrm{DM}$. The lowest concentrations of phytic acid in faeces were found in faeces of 1-week-old calves, presumably due to a low starter intake. The highest concentrations of phytic acid were found in 6-week-old calves: 2.34 and $2.11 \mathrm{~g} / \mathrm{kg} \mathrm{DM}(8.9$ and $4.7 \%$ of total P) in faeces of calves fed Standard and Telstar starter, respectively. In general, these findings are distinctly lower than those reported in faeces of pigs, poultry and rabbits (Marounek et al. 2000b; Dušková et al. 2001).

In conclusion, our results are in line with the opinion that phytic acid is decomposed in the ruminant digestive tract. In our experiment with calves, however, the hydrolysis of phytic acid apparently was not complete, as phytic acid was well measurable in faeces of most animals by capillary isotachophoresis. The phytic acid concentrations in faeces of calves were very variable, typically much lower than in faeces of monogastric animals. Future experiments should assess the digestibility of phytic acid in starter-fed calves.

\section{Koncentrace kyseliny fytové ve výkalech telat krmených startérovými koncentráty}

Přežvýkavci dokáží dobře využít kyselinu fytovou obsaženou v potravě. U mladých telat je ale systém trávení méně vyvinutý než u dospělých zviŕrat. Cílem naší práce bylo zjistit, zda kyselina fytováje $v$ trávicím traktu telat zcela hydrolyzována či nikoliv. Odebírali jsme proto vzorky výkalů z rekta 16 telat krmených startéry a stanovovali kyselinu fytovou metodou kapilární isotachoforézy. Vzorky byly odebírány u telat věku 1, 6 a 13 týdnů. Startérové koncentráty s obsahem 9,17 a 12,80 g kyseliny fytové v $1 \mathrm{~kg}$ sušiny (37,6 a 50,1\% celkového P) jsme telatům podávali ad libitum od 4. dne po narození. Odstav telat proběhl ve věku 6 týdnů. Kyselina fytová byla nalezena v 30 z 37 analyzovaných vzorků výkalů. Množství kyseliny fytové $v$ některých vzorcích nepostačovalo $\mathrm{k}$ přesnému stanovení. Nálezy kyseliny fytové značně kolísaly, od $1 \mathrm{mg}$ do $2,34 \mathrm{~g} \mathrm{v} 1 \mathrm{~kg}$ sušiny výkalů. Podíl fytátového $\mathrm{P}$ na celkovém obsahu P ve výkalech činil 0 až 8,9\%. Nejvyšší koncentraci kyseliny fytové jsme nalezli u telat právě odstavených, t.j. ve věku 6 týdnů. Výkaly telat odebrané ve věku 1,6 a 13 týdnů obsahovaly $8 \pm 4,477 \pm 265$ a $275 \pm 211 \mathrm{mg}$ kyseliny fytové $\mathrm{v} 1 \mathrm{~kg}$ sušiny (prüměry \pm SEM). Lze proto konstatovat, že hydrolýza kyseliny fytové $v$ trávicím traktu telat krmených startérovými koncentráty není úplná a její malá část přechází do výkalů.

\section{Acknowledgements}

This study received financial support from the Grant Agency of the Czech Republic (project No. 524/99/0101) and from the Ministry of Education, Youth and Sports of the Czech Republic (project No. 161700002). The authors wish to acknowledge Dipl. Ing. J. Poul for assistance and advice.

\section{References}

AOAC, 1980: Official Methods of Analysis. Association of Official Analytical Chemists. Washington, DC, pp. $125-142$

CLARK, W. D. Jr, WOHLT, J. E., GILBREATH, R. L., ZAJAC, P. K. 1986: Phytate phosphorus intake and disappearance in the gastrointestinal tract of high producing dairy cows. J. Dairy Sci. 69: 3151-3155

DUŠKOVÁ, D., MAROUNEK, M., BŘEZINA, P., 2001: Determination of phytic acid in feeds and faeces of pigs and poultry by capillary isotachophoresis. J. Sci. Food Agric. 81: 36-41

HATZACK, F., JOHANSEN, K. S., RASMUSSEN, S. K., 2000 : Nutritionally relevant parameters in low-phytate barley (Hordeum vulgare L.) grain mutants. J. Agric.Food Chem. $48: 6074-6080$

KMEŤ, V., BARAN, M., KALAČNJUK, G.I., 1990: Rumen Ecosystem Manipulation of Calves and Lambs by Microbial Preparations (in Slovak). Veda, Bratislava, pp.69-90

MAROUNEK, M., DUŠKOVÁ, D., SKŘIVANOVÁ, V., 2000a: Isotachophoretic determination of phytate phosphorus in faeces of cattle, pigs and hens. Reprod. Nutr. Dev. 40: 223

MAROUNEK, M., DUŠKOVÁ, D., SKŘIVANOVÁ, V., SAVKA, O. G., 2000b: Isotachophoretic determination of phytic acid in the feed and faeces of rabbits. Wld Rabbit Sci. 8: (Suppl. 1), 321-326 
MORSE, D., HEAD, H. H., WILCOX, C. J., 1992: Disappearance of phosphorus in phytate from concentrates in vitro and from rations fed to lactating dairy cows. J. Dairy Sci. 75: 1979-1986

NELSON, T. S., DANIELS, L. B., HALL, J. R., SHIELDS, L. G., 1976: Hydrolysis of natural phytate phosphorus in the digestive tract of calves. J. Anim. Sci. 42: 1509-1512

RAUN, A., CHENG, E., BURROUGHS, W., 1956: Phytate phosphorus hydrolysis and availability to rumen microorganisms. Agr. Food Chem. 4: 869- 871

REID, R. L., FRANKLIN, M. C., HALLSWORTH, E. G., 1947: The utilization of phytate phosphorus by sheep. Austr. Vet. J. 23: 136

YANKE, L. J., BAE, H. D., SELINGER, L. B., CHENG, K.-J., 1998: Phytase activity of anaerobic ruminal bacteria. Microbiology 144: 1565-1573 